\title{
Assessing the sustainability of lepidophagous catfish, Pachypterus khavalchor (Kulkarni, 1952), from a tropical river Panchaganga, Maharashtra, India
}

\author{
Sachin M. Gosavi ${ }^{1,2,3^{*+}}$ D, Sanjay S. Kharat ${ }^{1 \dagger}$, Pradeep Kumkar ${ }^{1}$ and Sandip D. Tapkir ${ }^{1,4}$
}

\begin{abstract}
Background: The Western Ghats of India, one of the global biodiversity hotspots and freshwater eco-regions, harbors several fish species which not just form the important part of the world's freshwater biodiversity yet in addition are the vital segment of livelihood of the neighborhood population. The rate of fish decline in the Western Ghats is alarming. The absence of organized study and data scarcity on basic biology and life history traits of several species could be one reason behind the decline, and thus it is difficult to execute conservation action/s. This is especially true, particularly for data-deficient species for which definite data related to distribution, population size, and trend is not available. The present study deals with the detailed investigation of population dynamics of catfish species, Pachypterus khavalchor, which is data-deficient species inhabiting the Western Ghats of India and forms an important component of freshwater inland fishery, providing nutritional and financial security to the local community.
\end{abstract}

Methods: Specimens for the present study were collected monthly for a period of 1 year from the River Panchaganga and length-frequency data were analyzed using FiSAT II software.

Results: Length-weight analysis of pooled (male + female) data suggested the fish exhibited higher exponent than expected under isometry, indicating the positive allometric growth of $P$. khavalchor in the Panchaganga River. The asymptotic length $(L \infty)$ and the growth rate $(K)$ were estimated as $149.63 \mathrm{~mm}$ and 0.71 year $^{-1}$ respectively. Potential longevity $\left(t_{\max }\right)$ and length at first capture $(L C)$ were estimated as 4.22 years and $73 \mathrm{~mm}$ respectively. The total $(Z)$, natural $(M)$, and fishing mortality $(F)$ were estimated as 2.23 year $^{-1}, 0.88$ year $^{-1}$, and 1.35 year $^{-1}$ respectively. The current exploitation rate $\left(E_{\text {cur }}=0.60\right)$ was found to be almost $90 \%$ that gives the maximum relative yield per recruit $\left(E_{\max }=0.67\right)$. Recruitment pattern revealed two peaks, suggesting the fish have two spawning bouts each year.

Conclusions: The stock of $P$. khavalchor in the Panchaganga River may be in near full exploitation under the current harvesting strategy, with a high chance of recruitment failure in the future. Additional studies on the reproductive biology of $P$. khavalchor would be particularly welcome for the imposition of the seasonal closure for effective conservation of stock.

Keywords: Lepidophagy, Fishery, Data scarcity, Freshwater ecosystem, Recruitment, Aquatic conservation, Mortality

\footnotetext{
* Correspondence: schn.gosavi@gmail.com

† Sachin M. Gosavi and Sanjay S. Kharat contributed equally to this work.

'Department of Zoology, Modern College of Arts, Science and Commerce, Ganeshkhind, Pune, Maharashtra 411 016, India

${ }^{2}$ Post Graduate Research Centre, Department of Zoology, Modern College of Arts, Science and Commerce, Shivajinagar, Pune, Maharashtra 411 005, India Full list of author information is available at the end of the article
} 


\section{Background}

The Western Ghats of India is well known for its exclusive biodiversity and also classified as a freshwater eco-region with more than 300 species of the freshwater fishes (Abell et al., 2008; Molur, Smith, Daniel, \& Darwall, 2011; Myers, Mittermeier, Mittermeier, Da Fonseca, \& Kent, 2000). Nearly $30 \%$ of the species inhabiting the Western Ghats have been categorized as threatened in the IUCN Red list (Dahanukar, 2011; Dahanukar, Raghavan, Ali, Abraham, \& Shaji, 2011; , Ramprasanth, Ali, \& Dahanukar, 2018a). However, several endemic and threatened species continue to be harvested at unsustainable levels through artisanal and open-access fisheries throughout the Western Ghats (Das et al., 2017; Keskar, Raghavan, Kumkar, Padhye, \& Dahanukar, 2017; Kharat \& Dahanukar, 2013; Prasad, Ali, Harikrishnan, \& Raghavan, 2012; Raghavan, Ali, Dahanukar, \& Rosser, 2011; Raghavan et al., 2018a). According to Darwall et al. (2018), another most important and fundamental cause for the freshwater biodiversity crisis is the insufficient consideration of impacts on freshwater ecosystems in decision-making and policy. However, decision-making and policy establishment require the reliable data on the population dynamics/trend, and thus the information inadequacy on population dynamics for majority of endemic species hindered the development of appropriate conservation action plans (Cooke, Paukert, \& Hogan, 2012; Dahanukar et al., 2011; Luiz, Woods, Madin, \& Madin, 2016; Morais et al., 2013). At present, the Western Ghats of India harbor 26 data-deficient species and majority of them are likely to be threatened with extinction (Dahanukar et al., 2011; Molur et al., 2011). Because of lack of substantial information on population dynamics, the data-deficient species are not at the forefront of the conservation agenda (Luiz et al., 2016; Morais et al., 2013; Possingham et al., 2002). As data deficiency not only means the absence of records, but it may indicate dangerously low abundance, Mace et al. (2008) clearly stated that "data-deficient species should be afforded the same degree of protection as a threatened species until more information is forthcoming." Keeping the above thought in view, it is fundamentally critical to have data on population biology parameters of known data-deficient species inhabiting the Western Ghats of India for their effective conservation and management.

The catfish genus Pachypterus consists of three species viz. Pachypterus acutirostris (Day, 1870) distributed in Irrawaddy, Sittang, and Bago rivers, Myanmar (Eschmeyer, Fricke, \& van der Laan, 2018; Kottelat, 2013); Pachypterus atherinoides (Bloch, 1794) distributed in river drainages of the Indian subcontinent north of the Cauvery, Bangladesh, Nepal, and Pakistan (Ahamed et al., 2018; Buragohain, 2018; Eschmeyer et al., 2018); and Pachypterus khavalchor (Kulkarni, 1952) which inhabits the Krishna River basin of Peninsular India (Dahanukar, Paingankar, Raut, \& Kharat,
2012; Eschmeyer et al., 2018). Each of these species is extremely delicious and having good market demands in their distribution range and thus provides dietary and financial advantage to the local community (Buragohain, 2018; Gosavi, Kharat, Kumkar, \& Navarange, 2018; Kumbar \& Lad, 2014). Since Pachypterus species forms an important part of the open-access fisheries, they are getting exploited in their distribution range leading to a huge decline in population (Buragohain, 2018; Kumbar \& Lad, 2014). In support to this, Dahanukar (2011) and Menon (1999) already pointed that several anthropogenic activities such as urbanization, industrial developments, and mining are contributing to dwindling population of $P$. khavalchor. Menon (2004) and Molur et al. (2011) further suggested that it could be a threatened species due to its fragmented population and non-availability of population data. As a result, presently, $P$. khavalchor is categorized as the "data deficient" species by IUCN (Dahanukar, 2011; Dahanukar et al., 2012; IUCN, 2018). However, despite of the variety of threats operating on the $P$. khavalchor presently, no conservation action plans are specifically directed towards conservation of this species. As a result of combined threats from different sources, data deficiency, and suggested possibility of the loss of this freshwater catfish species by (Menon, 1999), it is an immediate need to generate the data on the life history traits of $P$. khavalchor for instantaneous conservation action.

The persistence of any fish species in the given habitat is dependent on the life history traits of that species (Das et al., 2017, 2018; Kumar et al., 2014; Prasad et al., 2012; Raghavan et al., 2011, 2018a). Under the present environmental conditions, life history traits must generate sufficient recruitment for a given population to persist. In this context, considerable knowledge on lengthweight relationships, growth, population structure, mortality (natural and fishing), exploitation level, and recruitment pattern of an exploited stock is essential for planning and management of fisheries resources, mainly when the species form the important component of the artisanal fisheries and lies at the base of the higher food web (Das et al., 2017, 2018; Kumar et al., 2014). Therefore, present investigation was carried out for the assessment and evaluation of various life history traits of $P$. khavalchor using length-frequency data collected for one year. This study generates first of its kind information on the life history traits and population dynamics of the genus Pachypterus in general and P. khavalchor in particular.

\section{Methods}

Study area, fish collection, and measurements

Monthly samples were collected during June 2015 to May 2016 with the help of a small-scale artisanal fishermen from the Panchaganaga River $\left(17.28{ }^{\circ} \mathrm{N} ; 74.18{ }^{\circ} \mathrm{E}\right)$, 
Maharashtra, India. The fishing method employed in this area by local fishermen mainly includes the use of gill net and cast net of variable mesh size. Specimens $(n=427)$ were collected and brought to the laboratory in ice-filled boxes. Standard length (SL; a fish's body length from the tip of its snout to end of its last vertebrae; it includes everything except the caudal fin) and total length (TL; it is the length of a fish from the tip of its snout to the end of the longer lobe of its caudal fin) were measured for each specimen to the nearest $0.01 \mathrm{~mm}$ using a digital vernier caliper (Mitutoyo, Japan). Weight (W) was determined to the closest $0.01 \mathrm{~g}$ using digital weighing balance (Contech, India). Specimens were fixed in $10 \%$ formalin after all measurements and are in the departmental collection of Modern College of Arts, Science and Commerce, Ganeshkhind, Pune, Maharashtra, India. Growth, potential longevity, mortality, recruitment pattern, probability of capture, length structured virtual population analysis (VPA), relative yield per recruit, and biomass per recruit were estimated using FAO-ICLARM Stock Assessment Tools II (FiSAT II, version 1.2.2) software (Gayanilo Jr., Sparre, \& Pauly, 1998).

\section{Length-weight relationships (LWRs)}

LWR parameters were estimated according to the guidelines and equation given by Froese (2006):

$$
W={ }_{a} \mathrm{SL}^{b}
$$

where $W$ is the body weight (g), SL is the standard length $(\mathrm{cm}), " a$ " is the intercept, and " $b$ " is the slope of log-transformed linear regression. The coefficient of determination $\left(r^{2}\right)$ was estimated as the goodness of fit. Student's $t$ test was used to find out whether " $b$ " value significantly deviated from the expected cube value of 3 (Sokal \& Rohlf, 1987; Zar, 1984). The values of standard length and parameter $b$ were compared with values in FishBase (Froese \& Pauly, 2018). Analyses were performed using the program PAST version 3.13 (Hammer, Harper, \& Ryan, 2001).

\section{Population structure}

Frequency distribution forms the basis for the analysis, and thus standard length data were grouped in a lengthfrequency table with $2.5 \mathrm{~mm}$ as the smallest mid-length and $5 \mathrm{~mm}$ class intervals thereafter. To determine the population structure, contour plot was plotted using 10 $\mathrm{mm}$ length class of standard length (SL) in relation to different months.

\section{Growth and potential longevity}

Asymptotic length $(L \infty)$ and the growth coefficient $(K)$ were estimated using ELEFAN 1 method (Pauly, 1981, 1982; Pauly \& David, 1981; Pauly \& Morgan, 1987) by fitting the classical von Bertalanffy growth function (VBGF) as:

$$
L_{t}=L \infty^{*}\left[\left(1-\operatorname{Exp}\left(-K\left(t-t_{o}\right)\right]\right.\right.
$$

In Eq. 2, $L \infty$ represents asymptotic length; $K$ is the VBGF curvature parameter (growth constant), $L_{t}$ is the length at time $t$, and $t_{0}$ is the hypothetical length at the age length zero. Using growth parameters $(L \infty)$ and VBGF curvature parameter $(K)$, the Growth performance index $\left(\varnothing^{\prime}\right)$ was calculated as (Pauly, 1979; Pauly \& Munro, 1984):

$$
\left(\varnothing^{\prime}\right)=\log K+2 \log L 1
$$

The potential longevity $\left(t_{\max }\right)$ was obtained using the equation $t_{\max }=3 / K$, given by Pauly (1983). Maximum possible extreme length for this species was calculated using the support function available in FiSAT II (Formacion, Rongo, \& Sambilay, 1991). A selectivity curve was generated using linear regression fitted to the ascending data points from the plot of probability of capture against length, which was used to estimate the final value of length-at-first capture ( $L c$ or $\left.L_{50}\right)$.

\section{Mortality}

The length-converted catch curve was applied for the calculation of the total mortality (Z) (Pauly, 1983). Natural mortality $(M)$ was determined using the following Pauly's empirical equation (Pauly, 1980),

$$
\begin{aligned}
\ln (M)= & -0.0152-0.279 \ln \left(L_{\infty}\right) \\
& +0.6543 \ln (K)+0.463 \ln (T)
\end{aligned}
$$

where $T$ is the average annual temperature, which is $26^{\circ} \mathrm{C}$.

Fishing mortality was $(F)$ calculated by subtracting the $M$ value from the $Z$ value (Appeldoorn, 1984):

$$
F=(Z-M)
$$

Values of $F$ and $Z$ were used to calculate the current exploitation rate $\left(E_{\text {cur }}\right)$ as per the formula given by Gulland (1985):

$$
E_{\text {cur }}=F / Z
$$

Whether the present fishery resource status of study species is sustainable or not was assessed according to Etim, Lebo, and King (1999), where $Z / K$ ratio $\approx 2$ indicate over-exploitation.

\section{Exploitation}

The growth and mortality parameters were used as input for the length-structured virtual population analysis (VPA) analysis (Hilborn \& Walters, 1992). Further, the current level of exploitation $\left(E_{\text {cur }}\right)$ was estimated using 
relative yield per recruit $\left(Y^{\prime} / R\right)$ and biomass by recruit $\left(B^{\prime} / R\right)$ analysis with the Knife-Edge selection method (Beverton \& Holt, 1966). Values of $E_{50}$ (i.e., exploitation rate that resulted in a devalued of the unexploited biomass by $50 \%$ ) and $E_{\max }$ (i.e. exploitation rate producing maximum yield) were calculated by plotting $Y^{\prime} / R$ vs. $E_{\text {cur }}$ and of $B^{\prime} / R$ vs. $E_{\text {cur }}$.

\section{Probability of capture and recruitment pattern}

The probability of capture was estimated using the length-converted catch curve (Pauly, 1984). Recruitment pattern provides information related to the number of pulses per year and the relative strength of each pulse and therefore was calculated by reconstructing the recruitment pulses from a time series of length-frequency data (Moreau \& Cuende, 1991).

\section{Results}

Descriptive statistics of the sample sizes $(n)$, maximum and minimum values of SL, TL, and $W$ for male, female, and pooled data, and estimates of the LWR parameters are presented in Table 1. New maximum total length was recorded for $P$. khavalchor $(17.05 \mathrm{~cm})$ as compared to previously reported in FishBase $(15 \mathrm{~cm}$; Talwar \& Jhingran, 1991).

The frequency distribution of 427 individuals of different length class across months (Fig. 1) obtained during the present study indicated the occurrence of smallest individuals $(55-60 \mathrm{~mm})$ in August and largest individuals $(140-145 \mathrm{~mm})$ in January. The FiSAT II output of the restructured length frequency data of $P$. khavalchor population with the superimposed growth curve with the highest ideal fit index $(R n=0.339)$ is given in Fig. 2 . The asymptotic length $(L \infty)$ was estimated as $149.63 \mathrm{~mm}$ and coefficient of growth $(K)$ as 0.71 year $^{-1}$. The growth parameters estimated using the von Bertalanffy growth model for P. khavalchor and details of the mortality parameters calculated using the length converted catch curve (Fig. 3) are given in Table 2. Growth performance index $\left(\varnothing^{\prime}\right)$ was estimated as 4.201. Length at first capture $(L c)$ and the maximum possible predicted extreme length for $P$. khavalchor were found to be $73 \mathrm{~mm}$ and
$143.51 \mathrm{~mm}$ respectively. Total mortality $(Z)$ and natural mortality coefficient $(M)$ were found to be 2.23 year $^{-1}$ and 0.88 year $^{-1}$ respectively. Fishing mortality coefficient $(F)$ was found to be 1.35 year $^{-1}$.

The virtual population analysis (Fig. 4) revealed high natural mortality at a young age though the fishery principally targeted comparatively large sized individuals (from $52.5 \mathrm{~mm}$ onwards) as evident by the exponential decrease in survival rate. Exploitation levels estimated using relative yield-per-recruit $\left(Y^{\prime} / R\right)$ and relative biomass-per-recruit $\left(B^{\prime} / R\right)$ analysis based on knife edge selection were found to be $0.36\left(E_{50}\right)$ and $0.67\left(E_{\max }\right)$ respectively (Fig. 5; Table 2). The current level of exploitation $\left(E_{\mathrm{cur}}=0.60\right.$; Table 2$)$ was found to be almost $90 \%$ that gives the maximum relative yield per recruit $\left(E_{\max }=0.67\right)$ and almost twice than $E_{50}$, that maintained $50 \%$ of the spawning stock biomass (Fig. 5). Recruitment shows the bimodal pattern with the minor pulse in recruitment during the April-May and major pulse in September-October (Fig. 6). The minor pulse produced $28.13 \%$ and major pulse produced $29.62 \%$ recruitment.

\section{Discussion}

Uncontrolled exploitation of fishery resources by inland catch fisheries is considered as the second most noticeable threat to the freshwater fishes inhabiting the Western Ghats of India (Raghavan, Ali, Philip, \& Dahanukar, 2018; Raghavan et al., 2018a; Smith et al., 2011). However, presently, the gap in the research examining the impact of biological resource use on freshwater biodiversity or livelihoods is surprising. Fishery management is a dependent field, and in order to implement management plans and conservation actions, concrete data on demography parameters (growth and mortality rates), status of populations (stock assessments), and number of fish harvested (exploitation levels and rates) is the primary requirement (Raghavan et al., 2011, 2013, 2018,2018 a). Nonetheless, such data are readily available and confined to a few of the large-growing tropical cyprinids such as the members of the genus Tor (Bhat, Nautiyal, \& Singh, 2000; Raghavan et al., 2011, 2018a), with complete absence of information available on other

Table 1 Descriptive statistics, estimated parameters of LWRs $\left(W=a \times L^{b}\right)$ for Pachypterus khavalchor from Panchaganga River (tributary of Krishna River System) of the northern Western Ghats of India sampled during June 2015 to May 2016

\begin{tabular}{|c|c|c|c|c|c|c|c|c|c|c|c|c|c|c|c|}
\hline \multirow[t]{2}{*}{ Sex } & \multirow[t]{2}{*}{$n$} & \multicolumn{2}{|c|}{$\mathrm{SL}(\mathrm{cm})$} & \multicolumn{2}{|c|}{ TL $(\mathrm{cm})$} & \multicolumn{2}{|c|}{ W (g) } & \multicolumn{8}{|c|}{ LWRs regression parameters } \\
\hline & & $\overline{M i n}$ & $\operatorname{Max}$ & Min & Max & $\overline{M i n}$ & $\overline{\operatorname{Max}}$ & $\bar{a}$ & $\mathrm{Cl}$ of $\mathrm{a}$ & $b$ & $\mathrm{Cl}$ of $b$ & $\mathrm{Se}(b)$ & $r^{2}$ & $t$ & $p$ \\
\hline Male & 211 & 5.74 & 11.62 & 7.20 & 14.74 & 2.43 & 30.10 & 0.001 & $0.001-0.002$ & 3.586 & $3.476-3.693$ & 0.049 & 0.961 & 11.74 & $<0.0001$ \\
\hline Female & 216 & 6.56 & 14.22 & 7.94 & $17.05^{*}$ & 3.62 & 46.46 & 0.004 & $0.003-0.006$ & 3.183 & 3.059-3.317 & 0.058 & 0.933 & 3.15 & 0.0018 \\
\hline Pooled & 427 & 5.74 & 14.22 & 7.20 & 17.05 & 2.43 & 46.46 & 0.003 & $0.002-0.004$ & 3.336 & $3.286-3.451$ & 0.038 & 0.957 & 9.49 & $<0.0001$ \\
\hline
\end{tabular}

Italicized values represent significant difference

$S L$ standard length, $T L$ total length, $W$ Weight, $n$ number of samples, Min minimum, Max maximum, $a$ intercept, $b$ slope, Se(b) standard error of $b, C l 95 \%$ confidence limits, $r^{2}$ coefficient of determination, $t$ test for isometry, $p$ level of significance

*New length record 


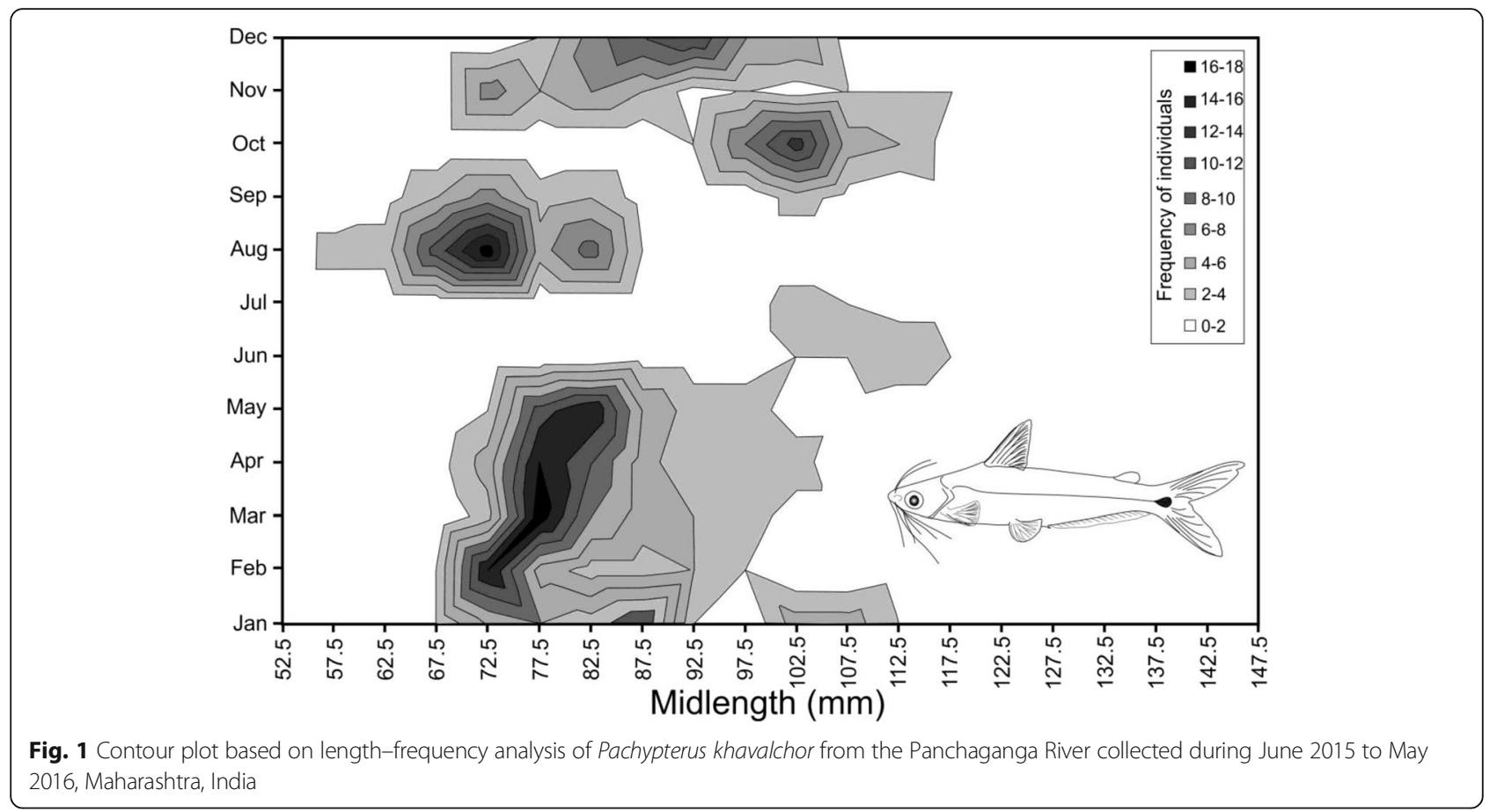

groups, including $P$. khavalchor which is presently categorized as the data-deficient species with possible speculation of its loss in the near future (Dahanukar, 2011; Dahanukar et al., 2012; IUCN, 2018; Menon, 1999). In this regard, the detailed investigation of the population dynamics of the data-deficient species inhabiting the Western Ghats of India is the key solution for imposing the conservation action plans. The present study provides the first of its kind information on the population dynamics and exploitation levels of the P. khavalchor and emphasized the instant conservation action for this species.

Fish growth can be measured as either isometric or allometric form (Gayanilo \& Pauly, 1997; Sarkar et al., 2013). In isometric growth pattern, both the length and weight of the fish increase at the same rate. On the contrary, allometric growth can be either positive or negative. Positive allometric growth represents that higher increment in weight as compared to length (fish becomes stouter or heavier or deeper-bodied). Negative allometric growth represents a higher increment in length as compared to weight (fish becomes slender or lighter) (Ogunola, Onada, \& Falaye, 2018; Wootton, 1998). Length-weight analysis of pooled (male + female) data suggested the fish exhibited significantly higher exponents $(b=3.336)$ than expected under isometry $(b=3)$, indicating the growth of $P$. khavalchor in the Panchaganga River was positive allometric. According to Beverton and Holt (1957), the departure of the ' $b$ ' value from three is rare in adult fishes. In our case, observed variation in the ' $b$ ' value could be attributed to several factors such as length range

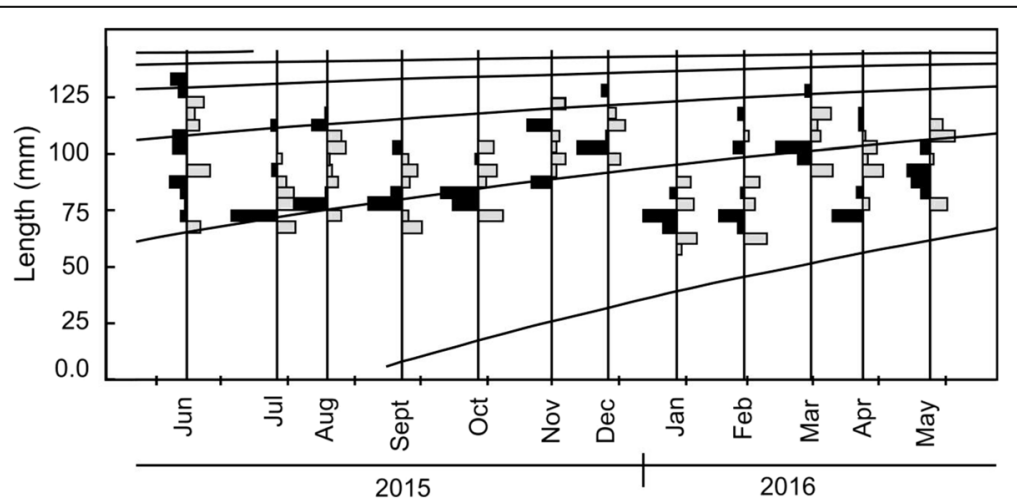

Fig. 2 The von Bertalanffy growth curve superimposed over length-frequency data of Pachypterus khavalchor from the Panchaganga River, Maharashtra, India 


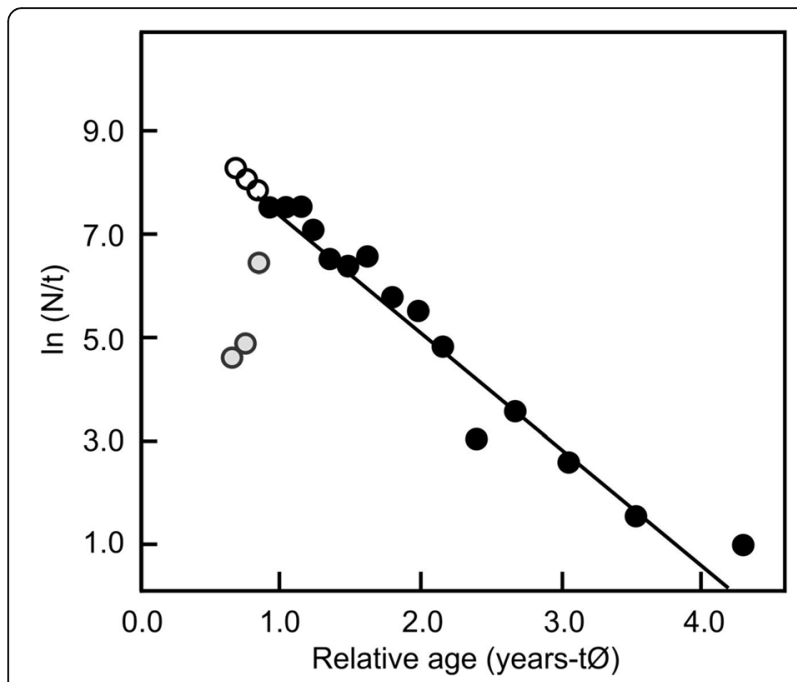

Fig. 3 Length-converted catch curve for Pachypterus khavalchor from the Panchaganga River, Maharshtra, India

used, season, stomach fullness, gonadal maturity, diet, sampling gear, mesh size, fishing pressure, and presence or absence of disease and parasite (Froese, 2006; Ogunola et al., 2018). However, these factors were not considered in the present study, and thus the observed variations in LWRs parameters could be due to the effect of a single factor or synergistic effect of multiple factors. Fish with ideal growth shows the coefficient of determination $\left(r^{2}\right)$ between 0.90 and $<1$ (Hanif, Siddik, Chaklader, Pham, \& Kleindienst, 2017). The $r^{2}$ value in the present study was found to be within expected range $(>0.93)$ indicates the proper fitness of the model for growth and good health status of the study species. Length-weight relationships (LWRs) data of the fishes have several applications such as indirect estimation of body weight based on the body length, calculation of condition indexes, and also for comparisons of species' growth trajectories (Chen et al., 2018; Froese, 2006; Ogunola et al., 2018). Additionally, LWRs are essential tools for the monitoring and conservation of fish populations, because they allow us to increase the effectiveness of management strategies, whether for control

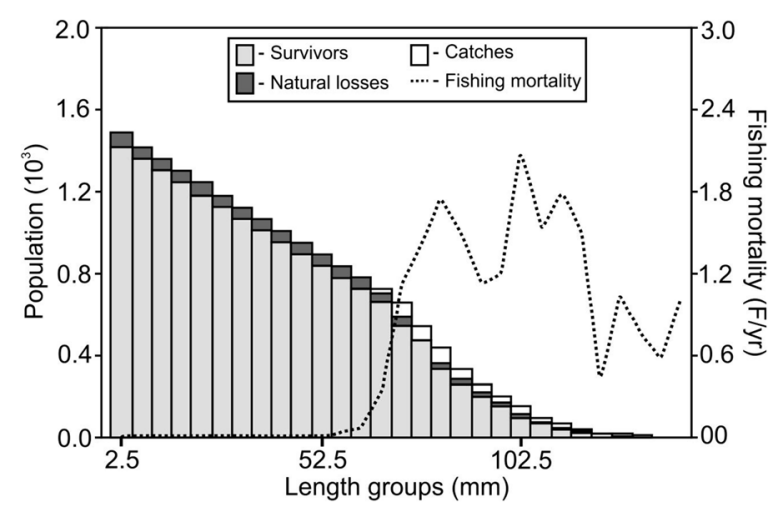

Fig. 4 Length-based virtual population dynamics for Pachypterus khavalchor from the Panchaganga River, Maharashtra, India

(e.g., introduced species), exploitation (e.g., inland fisheries), or conservation of species at risk (Rodríguez-Olarte, Taphorn, \& Agudelo-Zamora, 2018). Presently, no information is available from other known localities on the LWRs parameters of $P$. khavalchor thus comparative analysis cannot be performed.

The earlier study by Prasad et al. (2012) on Yellow Catfish Horabagrus brachysoma (Günther, 1864), which is another member from family Horabagridae showed asymptotic length $(L \infty)$ and VBGF $K$ value as $422 \mathrm{~mm}$ and 0.55 year $^{-1}$ respectively. In comparison with the results of Prasad et al. (2012), the P. khavalchor exhibit lower asymptotic length $(149.63 \mathrm{~mm})$ and high growth rate $\left(0.71\right.$ year $\left.^{-1}\right)$. The growth performance index value $\left(\emptyset^{\prime}\right)$ of 4.201 observed in the present study was found to be comparatively higher than that obtained for other tropical freshwater catfish species including those belonging to the families Schilbeidae (initially P. khavalchor was classified under the family Schilbeidae and is recently classified into family Horabagridae; $\varnothing^{\prime}$ between 2.18 and 2.78) (Etim et al., 1999), Claroteidae $\left(\varnothing^{\prime}=2.32\right)$ (Abowei \& Davies, 2009) and Synodontidae $\left(\varnothing^{\prime}=3.09\right)$ (Ofori-danson, Vanderpuye, \& De Graaf, 2001). High growth rates and growth performance index could be considered as the positive point in

Table 2 Growth, mortality, and exploitation parameters of Pachypterus khavalchor from the Panchaganga River, Maharshtra, India

\begin{tabular}{llll}
\hline Growth and longevity parameters & & Mortality and exploitation parameters & \\
\hline Asymptotic length $(L \infty)$ & $149.63 \mathrm{~mm}$ & Total mortality $(Z)$ & 2.23 year $^{-1}$ \\
VBGF growth constant $(K)$ & 0.71 year $^{-1}$ & Natural mortality $(M)$ & 0.88 year $^{-1}$ \\
Minimum length in sample $\left(L_{\min }\right)$ & $57.50 \mathrm{~mm}$ & Fishing mortality $(F)$ & 1.35 year $^{-1}$ \\
Maximum length in sample $\left(L_{\max }\right)$ & $142.5 \mathrm{~mm}$ & Length at first capture $(L C)$ & $73 \mathrm{~mm}$ \\
Growth performance index $\left(\varnothing^{\prime}\right)$ & 4.201 & Exploitation ratio $\left(E_{\text {cur }}\right)$ & 0.60 \\
Potential longevity $\left(t_{\max }\right)$ & 4.22 years & Exploitation ratio $\left(E_{\text {max }}\right)$ & 0.67 \\
Normalization constant $(a)$ of $L W R$ & 0.0032 & Exploitation ratio $\left(E_{50}\right)$ & 0.36 \\
Scaling power $(b)$ of $L W R$ & 3.33 & $Z / K$ ratio & 3.14 \\
\hline
\end{tabular}




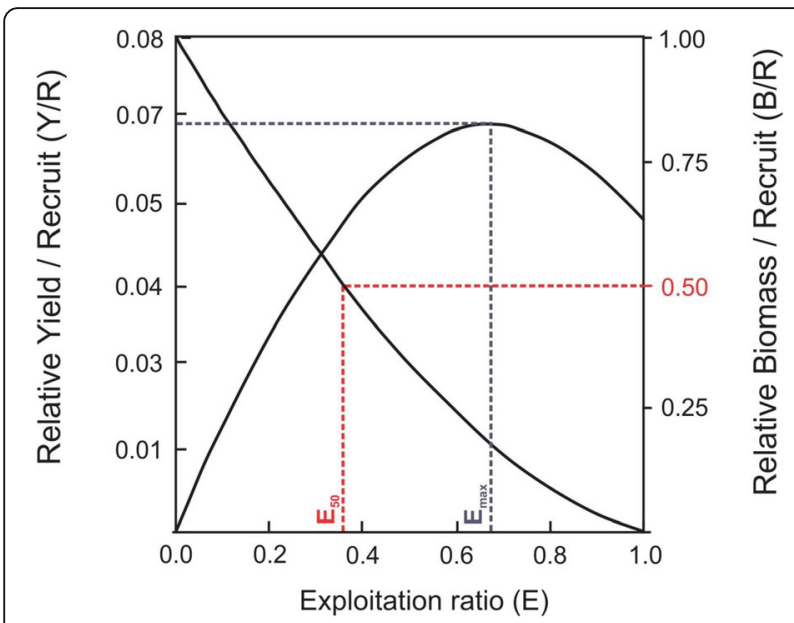

Fig. 5 Relative yield-per-recruit $\left(Y^{\prime} / R\right)$ and relative biomass-per-recruit $\left(B^{\prime} / R\right)$ analysis for Pachypterus khavalchor from the Panchaganga River, Maharashtra, India

terms of the aquaculture practice for this species (Raghavan et al., 2018a; Williams, Vijayalekshmi, Benziger, Karim, \& Nair, 2016). Additionally, high growth performance index value in $P$. khavalchor is an interesting observation because as phi prime $\left(\varnothing^{\prime}\right)$ is known to be highly species-specific parameter with their values being similar within related groups or taxa (Prasad et al., 2012). Interestingly, it has been shown that the $\varnothing^{\prime}$ value remains constant between populations of the same species (Pauly, 1979, 1981; Pauly \& Munro, 1984). Lack of data on $\varnothing^{\prime}$ across the distribution range of $P$. khavalchor restricts between population comparisons.

The length at first capture $(L c)$ and maximum possible predicted extreme length for $P$. khavalchor for the population was estimated to be $73 \mathrm{~mm}$ and $143.51 \mathrm{~mm}$, respectively, indicating that more than $50 \%$ of the population is being caught before they grow half of their maximum size. The $L c$ not only provides important information regarding the estimated real size of fish in the fishing area that are being caught by specific gear, but also enables the fishery

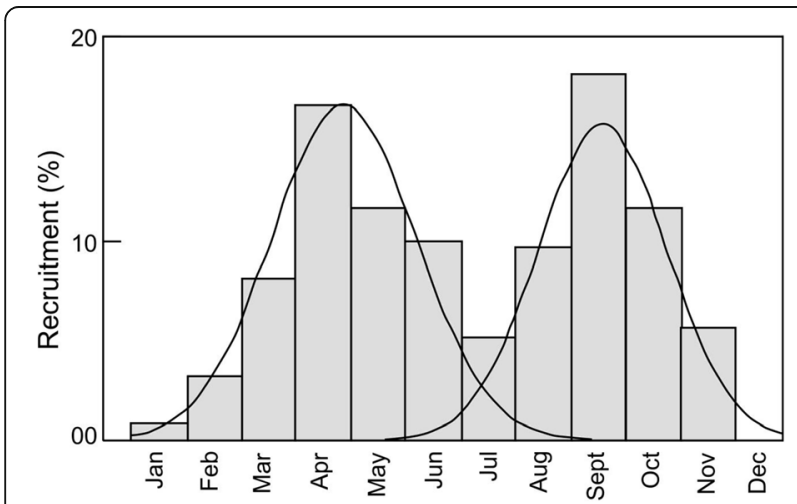

Fig. 6 Recruitment pattern for Pachypterus khavalchor from the Panchaganga River, Maharashtra, India managers to determine what should be the minimum size of the target species of a fishery (Kolding, Tirasin, \& Karenge, 1992; Prasad et al., 2012). Due to the complete absence of the published data on reproductive biology parameters of this species, it is hard to interpret whether the immature individuals are exploited. However, several times extremely small-sized $P$. khavalchor population was observed $(57.50 \mathrm{~mm}$; minimum size in the study population) in the market for selling indicating that $P$. khavalchor is likely to be fished out before they mature and breed, subsequently contributing to reproductive damage and thus could be reducing the spawning stock of the species. Information on the size at maturity would be useful in re-appraised of mesh-size in this area to prevent cropping of small individuals. Clearly, investigations designed to understand various reproductive biology parameters of this species with special attention on the size at maturity would be particularly welcome.

Based on the virtual population analysis, it is clear that juvenile $(<52.5 \mathrm{~mm}$ in size) of the $P$. khavalchor facing high natural mortality in the study area. Absence of data on the natural mortality from other localities restricts our intraspecific as well congeneric comparison. However, the observed natural mortality $\left(0.88\right.$ year $\left.^{-1}\right)$ in $P$. khavalchor was found to be higher as compared to the other catfish species such as Clarotes laticeps (0.87) (Abowei \& Davies, 2009), Schilbe intermedius (0.81) (Etim et al., 1999) and Schilbe mystus (0.28) (Kolding et al., 1992). Such high natural mortality could be attributed to various factors such as predation, diseases, or different environmental stressors acting independently or synergistically (Caveriviere \& Toure, 1996; Raghavan et al., 2018a; Richu, Dahanukar, Ali, Ranjeet, \& Raghavan, 2018). However, the exact information on the factor/s causing higher natural mortality at the small size of $P$. khavalchor is not known and thus need further investigation. On the contrary, mortality of larger size individuals $(>67.5 \mathrm{~mm})$ indicating the greater fishing pressure. According to the Kumbar and Lad (2014) various catfish species inhabiting the Krishna River basin including $P$. khavalchor is subjected to various threats such as habitat modifications caused by dams, habitat loss due to sand mining, rapid development in urbanization, increasing pollution, overexploitation, destructive fishing methods (dynamite fishing). Higher fishing mortality in $P$. khavalchor could be attributed to the any of the above mentioned factor/s.

According to Gulland (1985), in an optimally exploited stock, fishing mortality should be equal to natural mortality $(F=M)$, resulting in an exploitation rate $(E)$ of 0.50 . However, according to Patterson (1992) the fishing rate satisfying the optimal exploitation level of 0.5 tended to reduce the fish stock abundance and, hence, the former author suggested that ' $E_{\text {cur }}$ ' should be maintained at 0.40 
for optimal exploitation of those stocks. In the present study the estimates of the fishing mortality $\left(1.35\right.$ year $\left.^{1}\right)$ for $P$. khavalchor is close to twice as compared to natural mortality $\left(0.88\right.$ year $\left.^{-1}\right)$ and exploitation $(E)$ is 0.60 indicating that the study species is being heavily exploited and overfished in the study area. The results are further supported by the $Z / K$ ratio (3.14), since according to Etim et al. (1999), $Z / K$ ratio $\approx 2$ indicate over-exploitation. The current exploitation level $\left(E_{\text {cur }}\right)$ was estimated at 0.60 for $P$. khavalchor with predicted $E_{50}$ and $E_{\max }$ of 0.36 and 0.67 respectively. This indicates that the present level of exploitation $\left(E_{\text {cur }}=0.60\right)$ is almost $90 \%$ that gives the maximum level of exploitation $\left(E_{\max }=0.67\right)$ and almost twice than $E_{50}$ that maintained $50 \%$ of the spawning stock biomass. For continuity of the species in the study area, it is necessary to maintain at least $50 \%$ of the spawning stock and therefore the current level of exploitation need to decrease from $0.60\left(E_{\text {cur }}\right)$ to 0.36 $\left(E_{50}\right)$ which is approximately by $44 \%$. Presence of the two bouts based on recruitment patterns indicating that $P$. khavalchor may exhibit two or extended spawning periods per year. However, a detailed investigation of various reproductive biology parameters such as gonado-somatic index, size at maturity, sexual dimorphism, spawning season, fecundity and spawning frequency is suggested.

\section{Conclusions and implications for conservation}

It is clear from the present investigation that $P$. khavalchor population facing the high rate of the exploitation and high fishing pressure in the study area of the Krishna River system hence appears to be unsustainable. Since currently there are no management plans for $P$. khavalchor, a chance of loss of this species is more in the near future. The rational exploitation of this species can be achieved by the implementation of conservation and management plans such as (a) decreasing the present fishing pressure by $44 \%$ of its current level, (b) size-limit regulation by gradually increasing the fishing gears mesh size, (c) reconsidering the design of the fishing methods adopted in the Krishna River to prevent capture of smaller individuals, (d) strict implementation of rules and regulations in order to minimize destructive fishing methods such as dynamite fishing, (e) time-limit regulation by restricting the fishing during spawning period, and (f) declaring a portion of the rivers inhabited by $P$. khavalchor as a natural history reserve (in support to Menon, 1999) to ensure persistence of this fish. Furthermore, due to lack of information across the distribution range, extensive and uncontrolled exploitation, and possibility of being threatened species, it is recommended to use the flag of potentially threatened (PT) species along with data-deficient status by IUCN as per suggestion by Jarić, Courchamp, Gessner, and Roberts (2016), so as to increase the focus of the scientific community and conservation decision-makers on $P$. khavalchor in order to avoid the risk that necessary conservation measures are implemented too late.

\section{Abbreviations \\ $B^{\prime} / R$ : Relative Biomass per recruit; E: Exploitation; $E_{\text {cur: }}$ Current exploitation rate; F: Fishing mortality; FiSAT II: FAO-ICLARM Stock Assessment Tools II; K: Growth coefficient; Lo: Asymptotic length; LWRs: Length-weight relationships; M: Natural mortality; SL: Standard length; T: Average annual temperature; TL: Total length; $t_{\text {max }}$ : Potential longevity; VBGF: Von Bertalanffy growth function; VPA: Virtual population analysis; W: Weight; Y'R: Relative yield per recruit; Z: Total mortality}

\section{Acknowledgements}

The authors sincerely acknowledge the constant support, encouragement and valuable suggestions by Neelesh Dahanukar, Indian Institute of Science Education and Research (IISER) Pune, Maharashtra, India. Thanks are also due to the Annapa, Sunny, Nitin Sawant, Swapnil Chaudhary, Siddhesh Rajpure, Chandani Verma, Pankaj Gorule and Manoj Pise for their support during the field work and specimen collection.

\section{Funding}

The research was supported by grants from University Grant Commission (UGC) under minor research project, file number 47-914/14 (WRO) New Delhi and Department of Biotechnology (DBT), Government of India under DBT-

STAR College Scheme awarded to Modern College of Arts, Science and Commerce, Ganeshkhind, Pune, Maharashtra, India.

Availability of data and materials

Data is available with corresponding author and will be made available on request.

\section{Authors' contributions}

SMG and SSK designed the experiment, performed practical work, carried out the data analysis, and wrote the manuscript. PK and SDT contributed to the animal collection and practical work. All authors read and approved the final manuscript.

\section{Ethics approval}

In India, Indian researchers do not require permission to collect animals unless the locality of collection is in wildlife protected area (The Gazette of India, REGD. NO. D.L.-33004/99, section 17). Moreover, the present study was carried out in accordance with institutional and national guidelines for handling the experimental animals.

Consent for publication

No human subjects are included. No individual person's data are included.

\section{Competing interests}

The authors declare that they have no competing interests.

\section{Publisher's Note}

Springer Nature remains neutral with regard to jurisdictional claims in published maps and institutional affiliations.

\section{Author details}

${ }^{1}$ Department of Zoology, Modern College of Arts, Science and Commerce, Ganeshkhind, Pune, Maharashtra 411 016, India. ${ }^{2}$ Post Graduate Research Centre, Department of Zoology, Modern College of Arts, Science and Commerce, Shivajinagar, Pune, Maharashtra 411 005, India. ${ }^{3}$ Department of Zoology, Maharashtra College of Arts, Science and Commerce, Mumbai, Maharashtra 411 008, India. ${ }^{4}$ Department of Zoology, Savitribai Phule Pune University, Ganeshkhind, Pune, Maharashtra 411 007, India. 
Received: 1 December 2018 Accepted: 17 January 2019

\section{Published online: 06 February 2019}

\section{References}

Abell, R., Thieme, M. L., Revenga, C., Bryer, M., Kottelat, M., Bogutskaya, N., .. Petry, P. (2008). Freshwater ecoregions of the world: A new map of biogeographic units for freshwater biodiversity conservation. Bioscience, 58(5), 403-414. https://doi.org/10.1641/B580507.

Abowei, J. F. N., \& Davies, A. O. (2009). Some population parameters of Clarotes laticeps (Rupell, 1829) from the freshwater reaches of lower Nun River, Niger Delta, Nigeria. American Journal of Scientific Research, 2, 10-19.

Ahamed, F., Saha, N., Nishat, M. A., Biswas, M. K., Sultana, M., Khatun, M. S., ... Ohtomi, J. (2018). Length-weight and length-length relationships of three small indigenous fishes from the Payra River, southern Bangladesh. Journal of Applied Ichthyology, 34(3), 777-779.

Appeldoorn, R. S. (1984). The effect of size on mortality of small juvenile conchs (Strombus gigas Linne and S. costatus Gmelin). Journal of Shellfish Research, $4(1), 37-43$

Beverton, R. J. H., \& Holt, S. J. (1957). On the dynamics of exploited fish population. Fisheries Investigations, 11, 1-533. https://doi.org/10.1007/978-94 011-2106-4_2.

Beverton, R. J. H., \& Holt, S. J. (1966). Manual of methods for fish stock assessment: Part 2: tables of yield functions. In FAO Fisheries Technical Paper/ FAO Document, 38, (p. 67)

Bhat, J. P., Nautiyal, P., \& Singh, H. R. (2000). Population structure of Himalayan Mahseer, a large cyprinid fish in the regulated foothill section of the river Ganga. Fisheries Research, 44(3), 267-271. https://doi.org/10.1016/S01657836(99)00083-1.

Bloch, M. E. (1794). Naturgeschichte der ausländischen Fische. Kessinger Verlag, Berlin. v. 8:i-iv + 1-174, Pls. 361-396.

Buragohain, A. (2018). Length-weight relationship and relative condition factor of Pachypterus atherinoides (Bloch, 1794) of Lachia river of Dhemaji District of Assam, India. International Journal of Recent Scientific Research, 9(1), 23328-23331. https:// doi.org/10.24327/JRSR

Caveriviere, A. \& Toure, D. (1996). Uncommon mortality of groupers at the end of the warm season in the coastal area of Senegal (West Africa). In F. Arreguln-Sanchez, J. L. Munro, M. C. Balgos, \& D. Pauly (Eds.), Biology, fisheries and culture of tropical groupers and snappers. ICLARM Conference Proceedings 48, (pp. 96-105). Manila: International Center for Living Aquatic Resources and Management (ICLARM)

Chen, S., Ding, H., Zhang, Z., Yao, N., Xie, C., \& Li, D. (2018). Length-weight relationships of three species in northern China. Journal of Applied Ichthyology, 34(5), 1214-1215. https://doi.org/10.1111/jai.13741.

Cooke, S. J., Paukert, C., \& Hogan, Z. (2012). Endangered river fish: Factors hindering conservation and restoration. Endangered Species Research, 17(2), 179-191. https://doi.org/10.3354/esr00426.

Dahanukar, N. (2011). Neotropius khavalchor. The IUCN Red List of Threatened Species 2011, (p. e.T172310A6864780). https://doi.org/10.2305/IUCN.UK. 2011-1.RLTS.T172310A6864780.en Downloaded on 30 Aug 2018.

Dahanukar, N., Paingankar, M., Raut, R. N., \& Kharat, S. S. (2012). Fish fauna of Indrayani River, northern Western Ghats, India. Journal of Threatened Taxa, 4(1), 2310-2317. https://doi.org/10.11609/JoTT.02771.2310-7.

Dahanukar, N., Raghavan, R., Ali, A., Abraham, R., \& Shaji, C. P. (2011). The status and distribution of freshwater fishes of the Western Ghats. In S. Molur, K. G. Smith, B. A. Daniel, \& W. R. T. Darwall (Eds.), The status and distribution of freshwater biodiversity in the Western Ghats, India, (pp. 21-48). Cambridge and Gland: IUCN and Coimbatore: Zoo Outreach Organisation.

Darwall, W., Bremerich, V., Wever, A. D., Dell, A. I., Freyhof, J., Gessner, M. O., Grossart, H. P., Harrison, I., Irvine, K., Jähnig, S. C., Jeschke, J. M., Lee, J. J., Lu, C., Lewandowska, A. M., Monaghan, M. T., Nejstgaard, J. C., Patricio, H., Schmidt-Kloiber, A., Stuart, S. N., Thieme, M., Tockner, K., Turak, E., \& Weyl, O. (2018). The alliance for freshwater life: A global call to unite efforts for freshwater biodiversity science and conservation. Aquatic Conservation: Marine and Freshwater Ecosystems, 28(4): 1015-1022. doi: https://doi.org/10.1002/aqc.2958

Das, A. K., Manna, R. K., Rao, D. S. K., Jha, B. C., Naskar, M., \& Sharma, A. P. (2017). Status of the River Krishna: Water quality and riverine environment in relation to fisheries. Aquatic Ecosystem Health \& Management, 20(1-2), 160-174. https://doi.org/10.1080/14634988.2017.1296312.

Das, I, Hazra, S, Das, S, Giri, S, Maity, S, \& Ghosh, S. (2018). Present status of the sustainable fishing limits for Hilsa Shad in the northern Bay of Bengal, India.
In Proceedings of National Academy of Sciences India, Section B Biological Sciences, (pp. 1-8). https://doi.org/10.1007/s40011-018-0963-3.

Day, F. (1870). On the freshwater fishes of Burma.-Part I. In Proceedings of the Zoological Society of London, 1869 (pt 3) (art. 3), (pp. 614-623).

Eschmeyer, W. N., Fricke, R., \& van der Laan, R. (eds). Catalog of fishes: Genera, species, references. http://researcharchive.calacademy.org/ research/ichthyology/catalog/fishcatmain.asp). Electronic version accessed 31 Aug 2018.

Etim, L., Lebo, P. E., \& King, R. P. (1999). The dynamics of an exploited population of a siluroid catfish (Schilbe intermidius Reupell 1832) in the Cross River, Nigeria. Fisheries Research, 40(3), 295-307. https://doi.org/10.1016/S01657836(98)00217-3.

Formacion, S. P., Rongo, J. M., \& Sambilay, V. C. (1991). Extreme value theory applied to the statistical distribution of the largest lengths of fish. Asian Fisheries Science, 4, 123-135.

Froese, R. (2006). Cube law, condition factor and weight-length relationships: History, meta-analysis and recommendations. Journal of Applied Ichthyology, 22(4), 241-253.

Froese, R., \& Pauly, D. (Eds). (2018). FishBase. World Wide Web electronic publication. Retrieved from www.fishbase.org. Version: 02/2018

Gayanilo, F. C., \& Pauly, D. (1997). FAO-ICLARM stock assessment tools (FiSAT). Reference manual, FAO Computerized Information Series (Fisheries). No. 8, ( $\mathrm{p}$. 262). Rome: $F A O$

Gayanilo Jr., F. C., Sparre, P., \& Pauly, D. (1998). The FiSAT user's guide. FAO computerized information series fisheries. Rome: ICLARM, DIFMAR 1999

Gosavi, S. M., Kharat, S. S., Kumkar, P., \& Navarange, S. S. (2018). Interplay between behavior, morphology and physiology supports lepidophagy in the catfish Pachypterus khavalchor (Siluriformes: Horabagridae). Zoology, 2(126), 185-191. https://doi.org/10.1016/..zool.2017.07.003.

Gulland, J. A. (1985). Fish stock assessment: A manual of basic methods. New York: Wiley.

Günther, A. (1864). Catalogue of the fishes in the British Museum. Catalogue of the Physostomi, containing the families Siluridae, Characinidae, Haplochitonidae, Sternoptychidae, Scopelidae, Stomiatidae in the collection of the British Museum. Catalogue of the fishes in the British Museum, 5, 1455.

Hammer, Ø., Harper, D. A. T., \& Ryan, P. D. (2001). PAST: Paleontological statistics software package for education and data analysis. Palaeontologia Electronica, 4(1), 9 https://palaeo-electronica.org/2001_1/past/issue1_01.htm.

Hanif, M. A., Siddik, M. A. B., Chaklader, M. R., Pham, H. D., \& Kleindienst, R. (2017). Length-weight relationships of three catfish species from a tributary of the Dhaleshwari River, Bangladesh. Journal of Applied Ichthyology, 33(6), 1261-1262. https://doi.org/10.1111/jai.13448.

Hilborn, R., \& Walters, C. J. (1992). Quantitative fisheries stock assessment. Boston: Springer. https://doi.org/10.1007/978-1-4615-3598-0.

IUCN (2018). The IUCN Red List of Threatened Species. Version 2017-3. www. iucnredlist.org. Downloaded on 31 Aug 2018.

Jarić, l., Courchamp, F., Gessner, J., \& Roberts, D. L. (2016). Potentially threatened: A data deficient flag for conservation management. Biodiversity and Conservation, 25(10), 1995-2000. https://doi.org/10.1007/s10531-016-1164-0.

Keskar, A., Raghavan, R., Kumkar, P., Padhye, A., \& Dahanukar, N. (2017). Assessing the sustainability of subsistence fisheries of small indigenous fish species: Fishing mortality and exploitation of hill stream loaches in India. Aquatic Living Resources, 30, 13. https://doi.org/10.1051/alr/2016036.

Kharat, S. S. \& Dahanukar, N. (2013). Population dynamics of the Hill Stream Loach Acanthocobitis mooreh (Sykes, 1839)(Cypriniformes: Nemacheilidae) from northern Western Ghats of India. Journal of Threatened Taxa, 5(11), 4562-4568. https://doi.org/10.11609/JoTT.03301.4562-8.

Kolding, J., Tirasin, E. M., \& Karenge, L. (1992). Growth, mortality, maturity and length-weight parameters of fishes in Lake Kariba, Africa. Naga, the ICLARM Quarterly, 15(4), 39-41.

Kottelat, M. (2013). The fishes of the inland waters of Southeast Asia: A catalogue and core bibliography of the fishes known to occur in freshwaters, mangroves and estuaries. Raffles Bulletin of Zoology, 27, 1-663.

Kulkarni, C. (1952). A new genus of schilbeid catfishes from the Deccan. Records of Indian Museum, 49, 231-238.

Kumar, R. S., Sarkar, U. K., Gusain, O., Dubey, V. K., Pandey, A., \& Lakra, W. S. (2014). Age, growth, population structure and reproductive potential of a vulnerable freshwater mullet, Rhinomugil corsula (Hamilton, 1822) from a Tropical River Betwa in Central India. Proceedings of National Academy of Sciences India, Section B Biological Sciences, 84(2), 275-286. https://doi.org/10.1007/s40011-013-0214-6. 
Kumbar, S. M., \& Lad, S. B. (2014). Diversity, threats and conservation of catfish fauna of the Krishna River, Sangli District, Maharashtra, India. Journal of Threatened Taxa, 6(1), 5362-5367. https://doi.org/10.11609/JoTT.o3394.5362-7.

Luiz, O. J., Woods, R. M., Madin, E. M., \& Madin, J. S. (2016). Predicting IUCN extinction risk categories for the world's data deficient groupers (Teleostei: Epinephelidae). Conservation Letters, 9(5), 342-350. https://doi.org/10.1111/ conl.12230.

Mace, G. M., Collar, N. J., Gaston, K. J., Hilton-Taylor, C. R. A. I. G., Akçakaya, H. R., Leader-Williams, N. I. G. E. L., ... Stuart, S. N. (2008). Quantification of extinction risk: IUCN's system for classifying threatened species. Conservation Biology, 22(6), 1424-1442. https://doi.org/10.1111/j.1523-1739.2008.01044.x.

Menon, A. G. K. (1999). Check list - fresh water fishes of India. Records of Zoological Survey of India. In Miscellaneous Publication Occasional Paper No. 175, (p. 366).

Menon, A. G. K. (2004). Threatened Fishes of India and Their Conservation, (p. 170). Kolkata: Zoological Survey of India.

Molur, S., Smith, K. G., Daniel, B. A., \& Darwall, W. R. T. (2011). The Status and Distribution of Freshwater Biodiversity in the Western Ghats, India. Cambridge and Gland: IUCN, and Coimbatore: Zoo Outreach Organisation.

Morais, A. R., Siqueira, M. N., Lemes, P., Maciel, N. M., De Marco, P., \& Brito, D. (2013). Unraveling the conservation status of data deficient species. Biological Conservation, 166, 98-102. https://doi.org/10.1016/j.biocon.2013.06.010.

Moreau, J., \& Cuende, F. X. (1991). On improving the resolution of the recruitment patterns of fishes. ICLARM Fishbyte, 9(1), 45-46.

Myers, N., Mittermeier, R. A., Mittermeier, C. G., Da Fonseca, G. A., \& Kent, J. (2000). Biodiversity hotspots for conservation priorities. Nature, 403(6772), 853. https://doi.org/10.1038/35002501.

Ofori-danson, P. K., Vanderpuye, C. J., \& De Graaf, G. J. (2001). Growth and mortality of the catfish, Hemisynodontis membranaceus (Geoffroy St. Hilaire), in the northern arm of Lake Volta, Ghana. Fisheries Management and Ecology, 8, 37-45. https://doi.org/10.1046/j.1365-2400.2001.00214.x.

Ogunola, O. S., Onada, O. A., \& Falaye, A. E. (2018). Preliminary evaluation of some aspects of the ecology (growth pattern, condition factor and reproductive biology) of African pike, Hepsetus odoe (Bloch 1794), in Lake Eleiyele, Ibadan, Nigeria. Fisheries and. Aquatic Sciences, 21(1), 12. https://doi.org/10.1186/ s41240-018-0087-y.

Patterson, K. (1992). Fisheries for small pelagic species: An empirical approach to management targets. Reviews in Fish Biology and Fisheries, 2(4), 321-338.

Pauly, D. (1979). Gill size and temperature as governing factors in fish growth: a generalization of von Bertalanffy's growth formula. Berichte des Instituts für Meereskunde an der Univ. Kiel. No. 63, xv + 156 p.

Pauly, D. (1980). On the interrelationships between natural mortality, growth parameters, and mean environmental temperature in 175 fish stocks. ICES Journal of Marine Science, 39(2), 175-192. https://doi.org/10.1093/ icesjms/39.2.175.

Pauly, D. (1981). The relationships between gill surface area and growth performance in fish: A generalization of von Bertalanffy's theory of growth. Meeresforsch, 28(4), 251-282.

Pauly, D. (1982). Theory and management of tropical fisheries. In D. Pauly, \& G. I. Murphy (Eds.), Studying single-species dynamics in a tropical multi-species context, (pp. 33-70) ICLARM Conference Proceeding 9.

Pauly, D. (1983). Some simple methods for assessment of tropical fish stocks. FAO Fisheries Technical Paper, 234, 52.

Pauly, D. (1984). Fish population dynamics in tropical waters: A manual for use with programmable calculators, (vol. 8, p. 325). Manila: ICLARM.

Pauly, D., \& David, N. (1981). ELEFAN I, a BASIC program for the objective extraction of growth parameters from length-frequency data. Meeresforschung, 28, 205-211.

Pauly, D., \& Morgan, G. R. (Eds.) (1987). Length-based methods in fisheries research. ICLARM Conference Proceeding, 13, 468.

Pauly, D., \& Munro, J. L. (1984). Once more on the comparison of growth in fish and invertebrates. ICLARM Fishbyte, 2, 21

Possingham, H. P., Andelman, S. J., Burgman, M. A., Medellín, R. A., Master, L. L., \& Keith, D. A. (2002). Limits to the use of threatened species lists. Trends in Ecology and Evolution, 17(11), 503-507. https://doi.org/10.1016/S01695347(02)02614-9.

Prasad, G., Ali, A., Harikrishnan, M., \& Raghavan, R. (2012). Population dynamics of an endemic and threatened yellow catfish, Horabagrus brachysoma (Günther) from River Periyar, Kerala, India. Journal of Threatened Taxa, 4(2), 2333-2342. https://doi.org/10.11609/JoTT.o2590.2333-42.
Raghavan, R., Ali, A., Dahanukar, N., \& Rosser, A. (2011). Is the Deccan Mahseer, Tor khudree (Sykes, 1839), (Pisces: Cyprinidae) fishery in the Western Ghats sustainable? A participatory approach to stock assessment. Fisheries Research, 110(1), 29-38. https://doi.org/10.1016/j.fishres.2011.03.008.

Raghavan, R., Ali, A., Philip, S., \& Dahanukar, N. (2018). Effect of unmanaged harvests for the aquarium trade on the population status and dynamics of redline torpedo barb: A threatened aquatic flagship. Aquatic Conservation: Marine \& Freshwater Ecosystems, 28(3), 567-574. https://doi. org/10.1002/aqc.2895.

Raghavan, R., Dahanukar, N., Tlusty, M. F., Rhyne, A. L., Krishnakumar, K., Molur, S., \& Rosser, A. M. (2013). Uncovering an obscure trade: Threatened freshwater fishes and the aquarium pet trade. Biological Conservation, 164, 158-169. https://doi.org/10.1016/j.biocon.2013.04.019.

Raghavan, R., Ramprasanth, M. R., Ali, A., \& Dahanukar, N. (2018a). Population dynamics of an endemic cyprinid (Hypselobarbus kurali): Insights from an exploited reservoir fishery in the Western Ghats of India. Lakes \& Reservoirs: Research \& Management, 23(3), 250-255. https://doi.org/10.1111//re.12233.

Richu, A., Dahanukar, N., Ali, A., Ranjeet, K., \& Raghavan, R. (2018). Population dynamics of a poorly known serranid, the duskytail grouper Epinephelus bleekeri in the Arabian Sea. Journal of Fish Biology, 93(4), 741-744. https://doi. org/10.1111/jfb.13762.

Rodríguez-Olarte, D., Taphorn, D. C., \& Agudelo-Zamora, H. (2018). Length-weight relationships of fishes from western Caribbean freshwater drainages of Venezuela. Journal of Applied Ichthyology, 00, 1-5. https://doi.org/10.1111/jai. 13839 (early online version)

Sarkar, U. K., Khan, G. E., Dabas, A., Palhak, A. K., Mir, J. I., Rebello, J. C., ... Singh, S. P. (2013). Length-weight relationship and condition factor of selected freshwater fish species found in River Ganga, Gomti and Rapti, India. Journal of Environmental Biology, 23(34), 123-132.

Smith, K., Raghavan, R., Dahanukar, N., Molur, S., Holland, R., Hughes, A., \& Allen, D. (2011). Regional Synthesis for all taxa. In S. Molur, K. G. Smith, B. A. Daniel, \& W. R. T. Darwall (Eds.), The status of freshwater biodiversity in the Western Ghats, (pp. 87-108). Coimbatore: International Union for Conservation of Nature (IUCN) and Gland: Zoo Outreach Organization (ZOO).

Sokal, R. R., \& Rohlf, F. J. (1987). Introduction to biostatistics, (2nd ed., ). New York: Freeman.

Talwar, P. K., \& Jhingran, A. G. (1991). Inland fishes of India and adjacent countries, (p. 1158). New Delhi: Oxford-IBH Publishing Co. Pvt. Ltd.

Williams, S. E., Vijayalekshmi, P., Benziger, A., Karim, R., \& Nair, V. (2016). Artificial rearing of endemic red-tailed barb, Hypselobarbus kurali: A first report. North American Journal of Aquaculture, 78(2), 161-167. https://doi.org/10.1080/ 15222055.2015.1125978

Wootton, R. J. (1998). Ecology of teleost fishes, (2nd ed., ). Dordrecht: Kluwer Academic Publishers.

Zar, J. H. (1984). Biostatistical analysis, (p. 718). New Jersey: Prentice Hall.

\section{Submit your manuscript to a SpringerOpen ${ }^{\circ}$ journal and benefit from:}

- Convenient online submission

- Rigorous peer review

- Open access: articles freely available online

- High visibility within the field

- Retaining the copyright to your article

Submit your next manuscript at $>$ springeropen.com 